\title{
Mažos ir vidutinès galios kietuoju kuru kūrenamų ịrenginių kietųjų dalelių emisijų tyrimas
}

Jurij Tonkonogij,

Nerijus Pedišius,

Arūnas Stankevičius,

Andrius Tonkonogovas

Lietuvos energetikos institutas,

Šiluminiu įrengimu tyrimo ir

bandymu laboratorija,

Breslaujos g. 3, LT-44403 Kaunas

El.paštas: jurij.tonkonogij@lei.lt;

nerijus.pedisius@lei.lt;

arunas.stankevicius@lei.lt;

andrius.tonkonogovas@lei.lt
Eksperimentiškai ištirtos Lietuvoje gaminamų mažos nuo 6 iki $50 \mathrm{~kW}$ galios biokuru kūrenamų šildymo įrenginių, neturinčiu dūmų valymo įrangos, kietųjų dalelių (KD) emisijų masès koncentracijos. Nustatyta, kad granuliuotu kuru kūrenamų vandens šildymo katilų KD emisijos mažiausios. Iš devyniolikos tirtų tokių katilu, esant vardinei galiai, $74 \%$ jų KD emisijos buvo $<40 \mathrm{mg} / \mathrm{m}^{3}$ ir atitiko reikalavimus, keliamus 5 klasès katilams; $21 \%$ jų KD emisijos siekè $<60 \mathrm{mg} / \mathrm{m}^{3}$ ir tenkino 4 klasès reikalavimus. Malkomis kūrenamų katilų, neatsižvelgiant ị jų tipą, KD emisijų masès koncentracijos kito nuo $20 \mathrm{iki} 90 \mathrm{mg} / \mathrm{m}^{3}$ ir dauguma jų tenkino 4-5 klasès reikalavimus. Malkomis kūrenamoms krosnelèms dèl mažiau intensyvaus degimo ir tinkamai sureguliavus įsidegimą, taip pat pirminio ir antrinio oro degimui tiekimą pasiekiamas $\mathrm{KD}$ emisijų lygis $30-45 \mathrm{mg} / \mathrm{m}^{3}$.

Atlikti taip pat medienos skiedromis kūrenamo vidutinès $(500 \mathrm{~kW})$ vandens šildymo katilo dūmuose esančių $\mathrm{KD}$ dydžio ir tankio tyrimai. Ištirtas įrengto už katilo 6 elementų multiciklono veikimo efektyvumas ir KD prieš multicikloną ir už jo, atskirtu KD tankio pasiskirstymas pagal dydi. Nustatyta, kad KD emisijose yra daugiausia $0,2-0,3 \mu \mathrm{m}$ dydžio smulkiųjų dalelių. Multiciklone sulaikomų dalelių kiekis didžiausias $2-5 \mu \mathrm{m}$ intervale. Nors multiciklone iš dalies taip pat sulaikomos smulkiosios dalelès, bet siekiant užtikrinti mažas KD emisijas iš ịrenginių, kūrenamų biokuru, svarbu naudoti papildomą ịrangą, kuri leidžia sumažinti išmetamų smulkiųjų KD kiekį.

Eksperimentiniai rezultatai gerai koreliuoja su atliktos trumpos, kietuoju biokuru kūrenamų įrenginių KD emisijų charakteristikų ir jų mažinimo metodų, apžvalgos rezultatais. Patvirtinamas būtinumas, kad naudojant tokị kurą reikia taikyti metodus ir įrangą, užtikrinančius KD smulkesnių nei $1 \mu$ m sulaikymą. Elektrostatiniai KD nusodintuvai ir medžiaginiai arba keraminiai filtrai leidžia pasiekti geriausių rezultatus, o jų taikymo tyrimai sparčiai plètojami.

Raktažodžiai: kietųjų dalelių emisija, kietasis biokuras, katilas, ciklono efektyvumas

\section{IVADAS}

Pastaruoju metu sparčiai didejja biokuro naudojimas įvairaus tipo šildymo įrenginiuose. Tai reikalauja skirti daugiau dèmesio biokuru kūrenamiems įrenginiams tobulinti ir juose vykstantiems procesams tirti. Lietuvoje didžiąją dalį atsinaujinančiųjų energijos išteklių sudaro kietasis 
biokuras - įvairių rūšių medienos kuras, šiaudai ir kita augalinè biomasè, skirta energijai gaminti. Namų ùkiuose ir centralizuoto šildymo katilinèse dabar daugiausia naudojamas medienos kuras, nes jo ištekliai yra didžiausi ir lengviausiai pasiekiami, o deginimo technologijos ir ìrenginiai labiausiai išplètoti. Šio kuro potencialas dar nèra pakankamai tiksliai ịvertintas ir gali siekti $1300-1400$ ktne arba 7,45-8,10 mln. $\mathrm{m}^{3}$ medienos. Šiuo metu jau panaudojama apie 1085 ktne. Pastaraisiais 20 metų medienos kuro naudojimas nuolat augo. $2014 \mathrm{~m}$. duomenimis [1], namų ūkiuose buvo naudojama apie 508,7 ktne $(46,9 \%)$ bendrojo medienos kuro kiekio, o centralizuoto šildymo katilinèse ir kogeneracinèse elektrinèse atitinkamai 448,2 ktne (41,3\%). Likę kiekiai 128,1 ktne (11,8 \%) šildymui ir technologiniams procesams vykdyti buvo sunaudoti pramonès, paslaugų ir žemès ūkio sektoriuose. Sparti biokuro paklausa yra susijusi su vis intensyvesniu jo naudojimu ne tik naujai įrengtose šildymo sistemose, bet ir mažiau efektyviose senose, kurių taršos emisijos yra gerokai didesnès. Lietuvoje didžioji dalis namų ūkiuose eksploatuojamų šildymo sistemų yra techniškai pasenusios. Lyginant su naujosiomis sistemomis, jos išmeta $\mathfrak{i}$ aplinką didesnius kiekius teršalų, pavyzdžiui, anglies monoksido, organinių junginių, kietųjų dalelių ir policiklinių aromatinių angliavandenilių. Visi šie teršalai gerokai padidina gyvenamųjų rajonų, apšildomų biokuru, užterštumą, ypač šildymo sezono metu, o užterštumas kietosiomis dalelèmis (toliau - KD) $\mathrm{KD}_{10}$, kurių aerodinaminis skersmuo $<10 \mu \mathrm{m}$, dažnai yra didesnis nei reglamentuoja normos.

Šioms problemoms spręsti buvo kreipiama nepakankamai demesio, nes formuota nuomonè, kad biokuro panaudojimas energijai gaminti teikia tik privalumus - leidžia mažinti $\mathrm{CO}_{2}$ emisijas bei importuojamo iškastinio kuro naudojimą. Straipsnyje pateikiama KD emisijų iš biokuru kūrenamų mažos ir vidutinès galios įrenginių charakteristikų tyrimo, jų mažinimo priemonių taikymo ir leidžiamųjų normų ES šalyse apžvalga; Lietuvoje gaminamų ir tiekiamų rinkai mažos galios biokuru kūrenamų šildymo įrenginių KD emisijų ir jų mažinimo, naudojant multicikloną vidutinès galios vandens šildymo katilui, tyrimo rezultatai.

\section{KD EMISIJŲ MAŽINIMO METODŲ TYRIMŲ APŽVALGA}

\section{KD charakteristikos}

Vienas iš susidarančių teršalų degimo produktuose deginant kietajį biokurą yra KD, kurios apibūdinamos pagal jų dydị ir koncentraciją. Atsižvelgus i $\mathrm{KD}$ dydit, jos skirstomos i t stambiąsias $>10 \mu \mathrm{m}$, smulkiąsias $0,1-2,5 \mu \mathrm{m}$ ir labai smulkias $<0,1 \mu \mathrm{m}$. $\mathrm{KD}_{10}$ dalelès apima daleles $<10 \mu \mathrm{m}$. $\mathrm{KD}$ dydis ir koncentracija lemia daleliu judejjimo atmosferoje trajektoriją, atstumą ir trukmę. Stambiosios dalelès ant žemès nusèda per kelias valandas, bet smulkiosios gali išlikti atmosferoje kelias savaites. Dažniausiai nurodomos leidžiamosios KD masès koncentracijos neịvertinant stambiụjų ir smulkiųjų dalelių dalies. Tačiau būtent smulkiosios dalelès turi santykinai dideli kontaktinį paviršiaus plotą, jos gali būti potencialūs toksinių medžiagų pernešejai. Be to, jos gali prasiskverbti į žmogaus vidaus organus ir sukelti rimtų susirgimų.

Apibendrinta informacija, pagrịsta Švedijos mokslininkų tyrimais, nustatant $\mathrm{KD}$ masès koncentracijas ir jų dydžius kietuoju biokuru kūrenamų katilų, kurių galia nuo 1 iki $10 \mathrm{MW}$, dūmuose pateikta [2] darbe, iš kurio paaiškèja, kad mažesnès galios katilai privalomai aprūpinti multiciklonais, skirtais nusodinti stambiąsias $\mathrm{KD}$, o didesnès galios katilai papildomai aprūpinti elektrostatiniais nusodintuvais, skirtais smulkiosioms dalelèms nusodinti. Darbe taip pat parodyta, kad KD susidarymas priklauso nuo kuro ir pelenų sudeties, katilo tipo ir jo veikimo režimo. Išskiriami du KD tipai (modos). Smulkiųjų KD koncentracija pagal kieki yra gausiausia ir jų masès koncentracijos didžiausią reikšmę lemia 0,1-0,5 $\mu \mathrm{m}$ dalelès. Didelis šių dalelių kiekis turi ženklią ịtaką bendrąjai KD masès koncentracijos reikšmei.

Deginant miško atliekas katile ant ardyno, KD masès koncentracija prieš multicikloną dažniausiai siekia $350 \mathrm{mg} / \mathrm{Nm}^{3}$ (sausos dujos, $13 \% \mathrm{CO}_{2}$ ) ir yra didesnè nei deginant sausą medienos kurą. Kaip parodyta 1 pav., deginant sausą medienos kurą ant ardyno, už multiciklono išlieka dar ganètinai didelè smulkiųjų KD nuo 0,1 iki 0,5 $\mu \mathrm{m}$ koncentracija, kuri, kintant katilo apkrovai, kinta $50-100 \mathrm{mg} / \mathrm{Nm}^{3}$ ribose.

$0,1-0,5 \mu \mathrm{m}$ dydžio KD masès koncentracija, esant mažoms apkrovoms, išauga (1a pav.), 

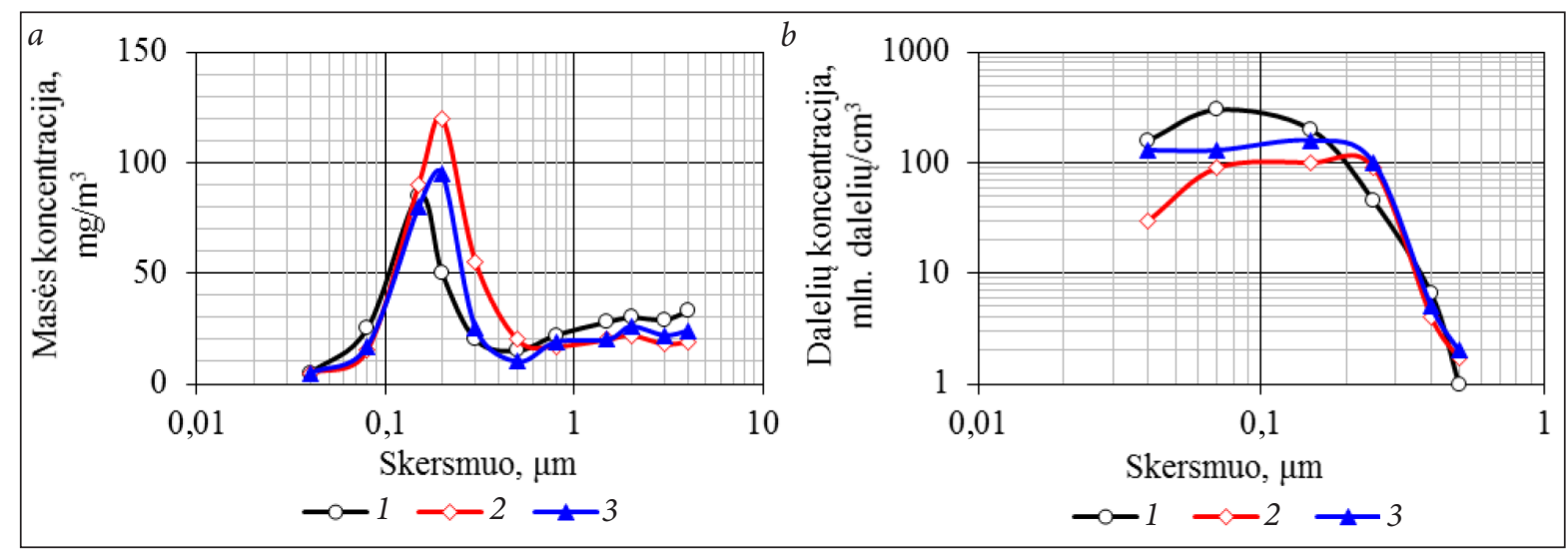

1 pav. Katilo, kūrenamo sausomis medienos atliekomis, degimo produktuose už multiciklono esančị KD masès koncentracijos ( $a$ ) ir jų kiekio (b) priklausomumas nuo dalelių dydžio ir katilo apkrovos [1]: 1,2 ir 3 - atitinkamai didžiausia, mažiausia ir vardinė apkrovos

bet pagal kiekị 0,04-0,2 $\mu \mathrm{m}$ dydžio KD daugiausia nustatoma esant didžiausioms apkrovoms (1b pav.).

Kūrenant drègnesniu kuru, pavyzdžiui, miško atliekomis, stebimas KD masès koncentracijos už multiciklono padidèjimas iki $150-175 \mathrm{mg} /$ $\mathrm{Nm}^{3}$. Šiame tyrime daroma išvada, kad suminè KD masès koncentracija už multiciklono gali kisti $50-175 \mathrm{mg} / \mathrm{Nm}^{3}$ ribose ir smulkiųjų $\mathrm{KD}$ iki $1 \mu \mathrm{m}-45-75 \mathrm{mg} / \mathrm{Nm}^{3}$.

Tai, kad KD emisijų koncentracija gali smarkiai kisti nuo daugelio veiksnių, susijusių ne tik su kuro rūšimi, bet ir su deginimo technologijos savitumais (pelenų susidarymo ịrenginyje sparta, jų kiekiu, degimo produktų srauto dydžiu per kuro sluoksnį ir jo sąveika su iš kuro sluoksnio išnešamais pelenais, nesudegusiu kuru ar suodžiais), patvirtina toliau pateikiami duomenys.

Mažos galios įrenginiuose, kūrenamuose biokuru, KD emisijas sudaro nevisiško degimo dalelès (suodžiai, besikondensuojančios organinès dalelès, apanglëjusios dalelès) ir pelenai (neorganiniai kuro elementai). Iš šių įrenginių pagrindinę emisijų dalį taip pat sudaro dalelès, kurių dydis gerokai mažesnis nei $1 \mu \mathrm{m}$.

1 lentelèje pateiktos ịvairių biokurą deginančių ịrenginių išmetamų didžiausios koncentracijos KD dydžių reikšmés pagal [3] rodo, kad didžiausią

1 lentelè. KD dydis esant didžiausiai koncentracijai, deginant biokurą ivairiuose įrenginiuose

\begin{tabular}{|c|c|c|}
\hline Kuras ( $\varphi$ - drègmè) & Irenginio tipas & Didžiausios koncentracijos dalelių dydis $\mu \mathrm{m}$ \\
\hline Malkos $\varphi=15-18 \%$ & Viryklè & $\begin{array}{l}\text { Isidegimas } 0,25 \text {; degimas } 0,16 \\
\text { galutinè degimo fazè } \sim 0,05\end{array}$ \\
\hline $\begin{array}{c}\text { Medienos skiedros } \\
\varphi=45-70 \%\end{array}$ & $\begin{array}{l}\text { Katilas, kūrenamas medienos } \\
\text { skiedromis }\end{array}$ & $\begin{array}{l}\text { Vidutinis skersmuo 0,0686 }\left(\mathrm{O}_{2}=6,2 \%\right) \\
\text { Vidutinis skersmuo } \sim 0,0957\left(\mathrm{O}_{2}=11,6 \%\right)\end{array}$ \\
\hline Malkos (buko) & Katilas, kūrenamas malkomis & 0,070 \\
\hline $\begin{array}{l}\text { Medienos skiedros } \\
\qquad \varphi=60 \%\end{array}$ & $\begin{array}{c}\text { Katilas, kūrenamas medienos } \\
\text { skiedromis }\end{array}$ & $\begin{array}{l}0,087\left(2,7 \% \mathrm{O}_{2}\right) ; 0,08\left(6,2 \% \mathrm{O}_{2}\right) \\
0,085\left(7,9 \% \mathrm{O}_{2}\right) ; 0,06\left(11,6 \% \mathrm{O}_{2}\right)\end{array}$ \\
\hline Medienos skiedros & Sūkurinis degiklis & 0,1 \\
\hline Malkos $\varphi=20 \%$ & Katilas, kūrenamas malkomis & $0,07-0,09$ \\
\hline Medienos granulès & $\begin{array}{c}\text { Katilas, kūrenamas medienos } \\
\text { granulèmis }\end{array}$ & 0,08 \\
\hline Malkos & Viryklè & $\begin{array}{l}\text { Isidegimas } 0,25 ; \text { degimas } 0,16 ; \\
\text { galutinè degimo fazè } 0,05\end{array}$ \\
\hline $\begin{array}{l}\text { Medienos skiedros } \\
\qquad \varphi=-40 \%\end{array}$ & Automatinis katilas & $0,07\left(6 \% \mathrm{O}_{2}\right) ; 0,072\left(9,3 \% \mathrm{O}_{2}\right) ; 0,065\left(14 \% \mathrm{O}_{2}\right)$ \\
\hline
\end{tabular}


koncentraciją sudaro smulkiosios dalelès, kurių dydis svyruoja nuo 0,06 iki $0,25 \mu \mathrm{m}$.

Atlikta nemažai kitų tyrimų [4-7], kurių rezultatai iš esmès patvirtina 1 lenteleje pateiktus rezultatus ir parodo, kad biokuru kūrenamų i̇renginių emisijose $\mathrm{KD}$ vidutinis dydis yra gerokai mažesnis nei $1 \mu \mathrm{m}$. Siekiant susieti KD emisijas su šildymo įrenginio gaminama energija, dažnai $\mathrm{KD}$ kiekis išreiškiamas ne KD mase, tenkančia emisijų tūrio vienetui $\left(\mathrm{mg} / \mathrm{m}^{3}\right)$, bet $\mathrm{KD}$ mase, tenkančia pagamintam šilumos energijos vienetui ( $\mathrm{mg} / \mathrm{MJ})$. Toks KD emisijų pateikimas patogus siekiant palyginti skirtingais ar panašiais principais veikiančių šildymo įrenginių taršos rodiklius.

2 pav. ir 2 lenteleje pateikti medienos kuru kūrenamų krosnių KD emisijų statistiniai duomenys, surinkti ịvairiose Europos šalyse [8].

Matyti, kad tarp didžiausių ir mažiausių KD emisijų verčių yra didelis skirtumas. Didžiausios $\mathrm{KD}_{10}$ emisijos 200-300 mg/MJ stebimos šildymo ịrenginiuose, kurie naudoja prastos kokybès kurą - medienos skiedras su dideliu kiekiu žemių priemaišų, ir kuriuose degimo procesas valdomas netobulai. Mažiausių $\mathrm{KD}_{10}$ emisijų vertè - $7 \mathrm{mg} / \mathrm{MJ}$ stebima deginant aukštos kokybės kurą (be žievès ir be žemių priemaišų) šildymo įrenginiuose su tinkamu degimo proceso valdymu.

KD emisijos, mažesnès nei $70 \mathrm{mg} / \mathrm{m}^{3}$, būdingos malkomis kūrenamiems katilams, veikiantiems dujų generavimo principu. Tačiau tiesioginio deginimo katilų $\mathrm{KD}$ emisijos gali siekti iki $300-540 \mathrm{mg} / \mathrm{m}^{3}$ [7].

\section{KD emisijų normos}

KD emisijų koncentracijas riboja aplinkosauginiai reikalavimai. KD emisijų leidžiamosios koncentracijos biokuru kūrenamuose mažos ir vidutinès galios įrenginiuose Europos šalyse ir Kanadoje pateiktos 3 lenteleje pagal [9] duomenis.

Matyti, kad atskirose šalyse KD emisijų normos skiriasi net iki 15-20 kartų. Griežčiausios normos nustatytos Vokietijoje. Tobulejjant biokuru kūrenamiems įrenginiams bei dūmų dujų valymo ịrangai, Europos šalyse numatomas šių normų griežtinimas.

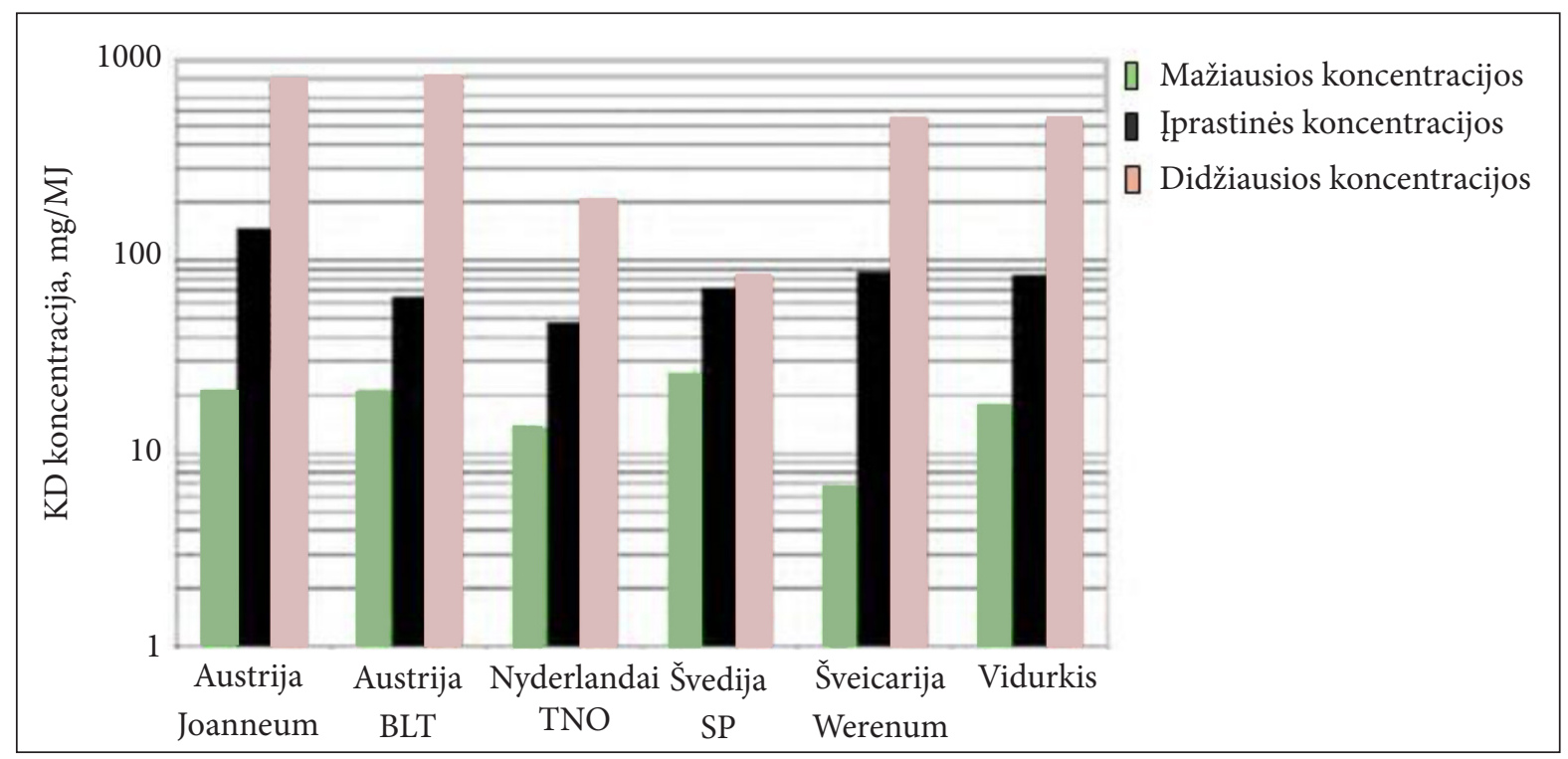

2 pav. Atskirų Europos šalių medienos kuru kūrenamų krosnių KD emisijų duomenys [8]

2 lentelè. KD emisijų reikšmių vidurkiai [8]

\begin{tabular}{|c|c|c|}
\hline Kategorija & $\mathrm{KD}_{10}$ emisijos, mg/Nm³ (mg/MJ) & $\mathrm{KD}_{2,5}$ emisijos, $\mathrm{mg} / \mathrm{Nm}^{3}$ (mg/MJ) \\
\hline lprastinès koncentracijos & $122(81)$ & $75(50)$ \\
\hline Didžiausios koncentracijos & 344 (229) & $182(121)$ \\
\hline Mažiausios koncentracijos & $11(7)$ & $9(6)$ \\
\hline
\end{tabular}


3 lentelè. Ivairiose šalyse galiojančios KD emisijų leidžiamosios koncentracijos [9]

\begin{tabular}{|c|c|c|c|}
\hline Šalis & Biokuru kūrenami įrenginiai & \multicolumn{2}{|c|}{ Leidžiamosios koncentracijos vertè } \\
\hline \multirow{4}{*}{ Vokietija } & \multirow[b]{2}{*}{$\begin{array}{l}\text { Kambariniai šildytuvai ir krosnys } \\
4-500 \text { kW galios, negranuliuota mediena }\end{array}$} & iki 2015 & nuo 2015 \\
\hline & & $\begin{array}{l}75 \mathrm{mg} / \mathrm{Nm}^{3} \\
(50 \mathrm{mg} / \mathrm{MJ})\end{array}$ & $\begin{array}{l}40 \mathrm{mg} / \mathrm{Nm}^{3} \\
(27 \mathrm{mg} / \mathrm{MJ})\end{array}$ \\
\hline & Kambariniai šildytuvai ir krosnys & $30-50 \mathrm{mg} / \mathrm{Nm}^{3}$ & $20-30 \mathrm{mg} / \mathrm{Nm}^{3}$ \\
\hline & 4-500 kW galios, granuliuota mediena & $20-33 \mathrm{mg} / \mathrm{MJ}$ & $13-20 \mathrm{mg} / \mathrm{MJ}$ \\
\hline \multirow{2}{*}{ Danija } & Vietinis šildymas & \multicolumn{2}{|c|}{$75 \mathrm{mg} / \mathrm{Nm}^{3}(50 \mathrm{mg} / \mathrm{MJ})$} \\
\hline & Centrinis šildymas & \multicolumn{2}{|c|}{$110 \mathrm{mg} / \mathrm{Nm}^{3}$ (73 mg/MJ) } \\
\hline \multirow{2}{*}{ Kanada } & Vietinis šildymas & \multicolumn{2}{|c|}{$206 \mathrm{mg} / \mathrm{Nm}^{3}$ (137 mg/MJ) } \\
\hline & Centrinis šildymas & \multicolumn{2}{|c|}{$600 \mathrm{mg} / \mathrm{Nm}^{3}$ (400 mg/MJ) } \\
\hline Austrija & Visi tipai $(<300$ kW) & \multicolumn{2}{|c|}{$90 \mathrm{mg} / \mathrm{Nm}^{3}(60 \mathrm{mg} / \mathrm{MJ})$} \\
\hline Airija & Visi tipai $(<300$ kW) & \multicolumn{2}{|c|}{$150 \mathrm{mg} / \mathrm{Nm}^{3}$ (100 mg/MJ) } \\
\hline Nyderlandai & & \multicolumn{2}{|c|}{ Nenormuojama } \\
\hline Švedija & Krosnys 3-5 kW galios, granuliuota mediena & \multicolumn{2}{|c|}{$100 \mathrm{mg} / \mathrm{Nm}^{3}$ (67 mg/MJ) } \\
\hline
\end{tabular}

\section{Dūmų valymo ịrangos efektyvumas}

Praktikoje KD emisijoms mažinti naudojama įvairiais principais veikianti įranga: ciklonai, multiciklonai, elektrostatiniai nusodintuvai ir ìvairūs filtrai. Vienas ar kitas dūmų valymo būdas parenkamas atsižvelgus ị naudojamo biokuro kokybę, reglamentuojamą dūmų išvalymo kokybę, kaštus ir šildymo ịrenginio veikimo ypatumus. Dūmų valymas nuo KD yra sudètingas procesas, priklausantis nuo daugelio veiksnių, vis dèlto įvairių autorių tyrimo duomenys leidžia aiškiai suskirstyti taikomus metodus ir ịrangą pagal efektyvumą $\mathfrak{i}$ apibrèžtus lygmenis. Pavyzdžiui, iš 4 lentelèje pateiktų [10] apibendrintų duomenų matyti, kad tik elektrostatiniai nusodintuvai ir medžiaginiai filtrai leidžia pasiekti aukščiausią dūmų išvalymo laipsnị.

Analogiški, bet išsamesni rezultatai pateikiami [11] (3 pav.). Taip pat iš čia matyti, kad medžiaginis filtras užtikrina aukštesni atskyrimo efektyvumą nei elektrostatinis nusodintuvas.
Elektrostatiniai nusodintuvai užtikrina $\mathrm{KD}_{10}$ bei $\mathrm{KD}_{2,5}$ atskyrimą iki $99 \%$ ir kiek daugiau. Apskritai pastarųjų dviejų tipų dūmų valymo įrangos efektyvumas mažiausiai priklauso nuo KD dydžio. Tai didelis jų privalumas ir pranašumas, palyginti su kitais valymo metodais. Tačiau bendrieji elektrostatinių nusodintuvų ir medžiaginių filtrų įrengimo ir eksploatacijos kaštai yra dideli, bet jų naudojimas, griežtejant taršos ribojimams, vis labiau plečiasi, netgi ị mažos galios šiluminių ịrenginių veikimo sriți. Šiuo požiūriu labai svarbūs tyrimai atliekami Austrijoje, Vokietijoje ir kitose šalyse, dalis kurių vykdoma pagal jungtinius šalių projektus [9]. Šių darbų tikslas - sukurti dūmų iš biokuru kūrenamų mažos galios, ịskaitant buitinius ịrenginius, valymo įrangą, taikant tiek elektrostatinį, tiek ir kitus metodus.

Nagrinejjant aplinkos taršos mažinimą ir kartu ịvertinant ịrangos įrengimo ir eksploatacijos kaštus bei taršos šaltinių tipų ir galios ịvairovę, būtina

4 lentelè. KD emisijų koncentracijos priklausomumas nuo biokuro rūšies ir dūmų valymo įrangos tipo [10]

\begin{tabular}{|c|c|c|c|}
\hline Kuras & Naudojama įranga & $\mathrm{KD}_{10}$ emisija, mg/m³ & $\mathrm{KD}_{2,5}$ emisija, $\mathrm{mg} / \mathrm{m}^{3}$ \\
\hline Žievès ar / ir drègna mediena & Nèra & 341 & 293 \\
\hline Žievès ar / ir drègna mediena & Ciklonas & 218 & 129 \\
\hline Drègna mediena & Nèra & 197 & 170 \\
\hline Drègna mediena & Ciklonas & 137 & 81 \\
\hline Kietasis biokuras & Medžiaginis filtras & 51 & 44 \\
\hline Kietasis biokuras & Elektrostatinis nusodintuvas & 27 & 24 \\
\hline
\end{tabular}




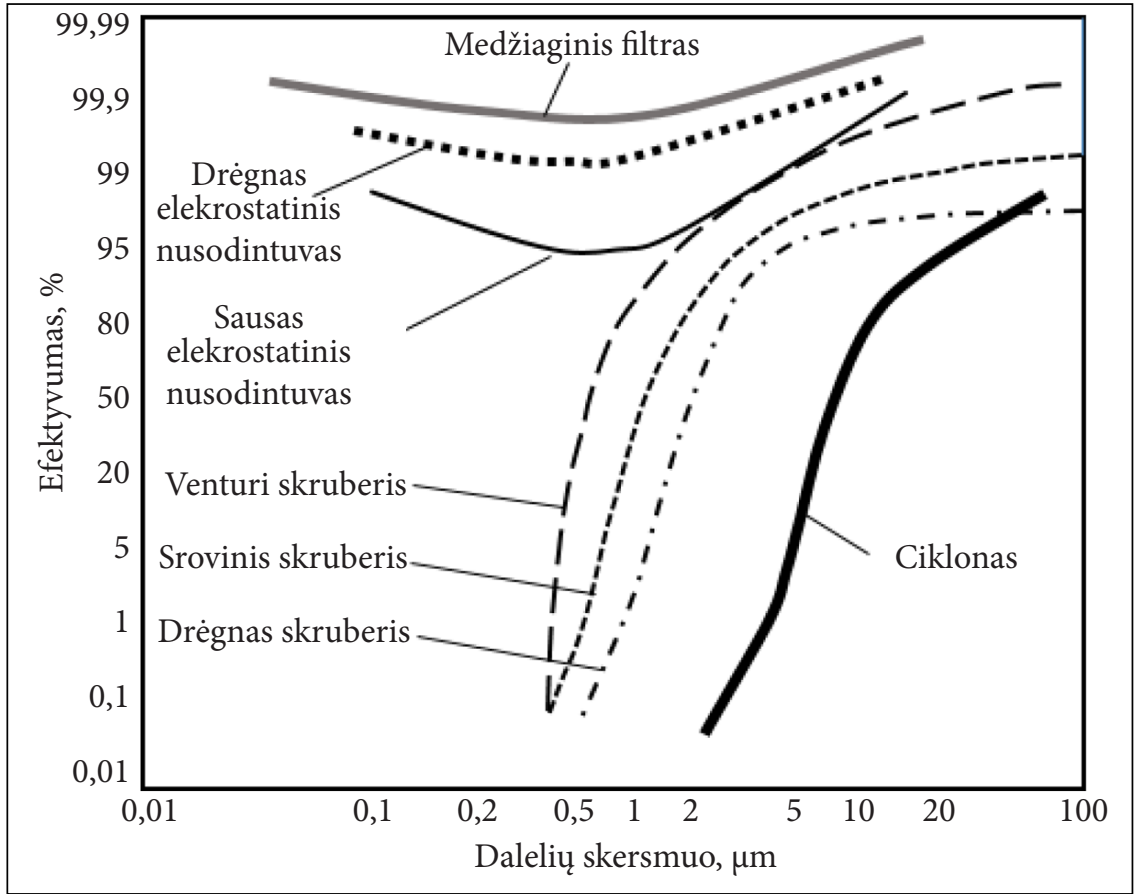

3 pav. Dūmų valymo įrangos efektyvumo priklausomumas nuo KD dydžio pagal [11]

taip pat tęsti mechaninių priemonių (ciklonų ir skruberių) konstrukcijų tobulinimo darbus, jų panaudojimą sąrankose su anksčiau nurodytais metodais. Kaip matyti iš 3 pav. pateiktų duomenų ir kitu tyrimų [11-14] rezultatų (4 pav.), ciklono efektyvumas gali siekti iki $95 \%$ esant KD dydžiui $\geq 5 \mu \mathrm{m}$, bet kai KD dydis $\leq 5-10 \mu \mathrm{m}$, efektyvumas smarkiai mažeja ir, palyginti su kitų tipų ịrenginiais, yra mažiausias.

Ciklonai pašalina didelị kiekị (apie $90 \%$ ) $\mathrm{KD}_{10}$ ir didesnių, taip pat mažą kiekị (apie $10 \%$ ) $\mathrm{KD}_{2,5}$ dalelių [10]. Viskas, kas pasakyta apie cikloną, iš esmès tinka ir multiciklonui, nors multiciklono efektyvumas yra kiek didesnis.

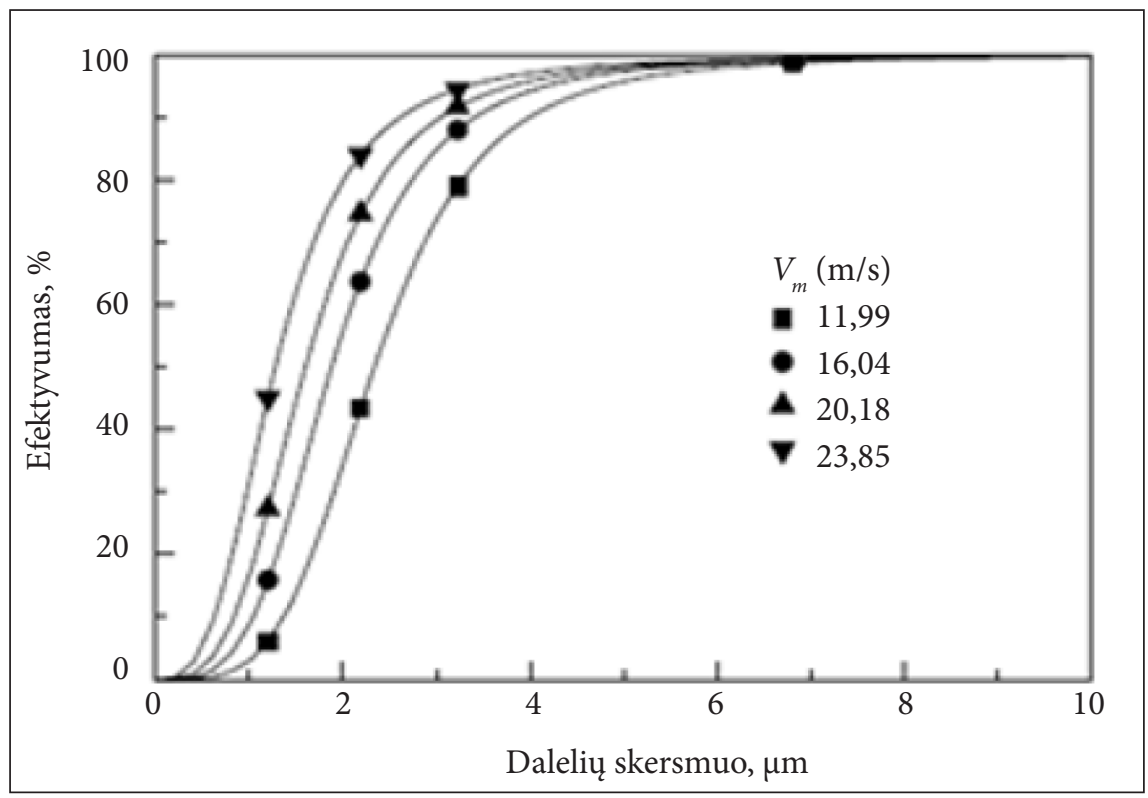

4 pav. Ciklono efektyvumo priklausomumas nuo KD dydžio pagal [12] 
Pateikta trumpa darbų apžvalga vieningai patvirtina, kad deginant biokurą, KD emisijų pagrindinę dalị sudaro smulkiosios dalelès, kurių dydis gali būti gerokai mažesnis nei $1 \mu \mathrm{m}$. Dideli poveikị KD koncentracijai ir jų dydžiui daro kuro rūšis ir jo kokybė bei deginimo ịrenginio tipas, jo galia ir veiksniai, susieti su degimo proceso vyksmu. Akivaizdu, kad smulkiosioms KD atskirti iš dūmų nepakanka ịprastinių ciklonų ir multiciklonų, būtina taikyti kitas priemones, pavyzdžiui, elektrostatinius nusodintuvus, įvairių tipų filtrus (medžiaginius ir keraminius) arba kitus metodus.

Dūmų iš buitinių mažos galios įrenginių, kūrenamų biokuru, valymas ypač keblus, nes šie ịrenginiai ganètinai skirtingos konstrukcijos, naudoja ìvairios rūšies kurą, degimo procesas dažniausiai nèra tinkamai reguliuojamas, dūmai pašalinami $\mathfrak{i}$ aplinką netoli ịrenginio, dèl silpnos sklaidos smarkiai didina vietini oro užterštumą smulkiosiomis kenksmingomis dalelèmis. Kaip rodo ES šalyse vykdomi darbai $[8,9]$, efektyvių ir mažų kaštų reikalaujančių šios problemos sprendinių siekiama taikant ịvairius metodus, kuriuos būtina pradèti tirti ir jų taikymą plètoti Lietuvoje.

\section{TYRIMO REZULTATAI}

Toliau pateikiami pradinių tyrimų rezultatai, siekiant ịvertinti gaminamų ir tiekiamų rinkai Lie- tuvoje mažos galios įrenginių, kūrenamų kietuoju biokuru, KD emisijų lygius ir juos palyginti su esamomis normomis bei ịvertinti multiciklono taikymo vidutinès galios vandens šildymo katilui efektyvumą.

\section{Lietuvoje gaminamų mažos galios ịrenginių $\mathrm{KD}$ emisijos}

Ištirtos Lietuvoje gaminamų mažos, nuo 6 iki $50 \mathrm{~kW}$, galios biokuru kūrenamų šildymo įrenginių, neturinčių dūmų valymo ịrangos, KD emisijų masės koncentracijos. Šiuos įrenginius sudarè vandens šildymo katilai, kūrenami medienos granulèmis (19 vnt.), malkine mediena (16 vnt.), iš kurių devyni duju generacinio tipo katilai ir septyni iprastiniai katilai bei septynios malkomis kūrenamos krosnelès.

Visų tiriamųjų įrenginių KD emisijų masès koncentracijos matuotos automatiniu izokinetiniu KD rinktuvu Isostac Basic HV, taikant standartizuotą metodą [15], įrenginiams veikiant vardine galia šiluminių ịrenginių tyrimo įrenginyje, kurio išsamus aprašymas pateiktas [16]. Du granulemis kūrenami 30 ir $50 \mathrm{~kW}$ galios katilai buvo taip pat tiriami esant jų dalinei, atitinkamai 6,3 ir 14,5 kW, galiai. KD masès koncentracijos matavimo izokinetiniu rinktuvu išplèstinè neapibrěžtis siekè 4,2\%.

5 pav. pateikti šių ịrenginių KD emisijų tyrimo rezultatai, esant $10 \% \mathrm{O}_{2}$ kiekiui dūmuose.

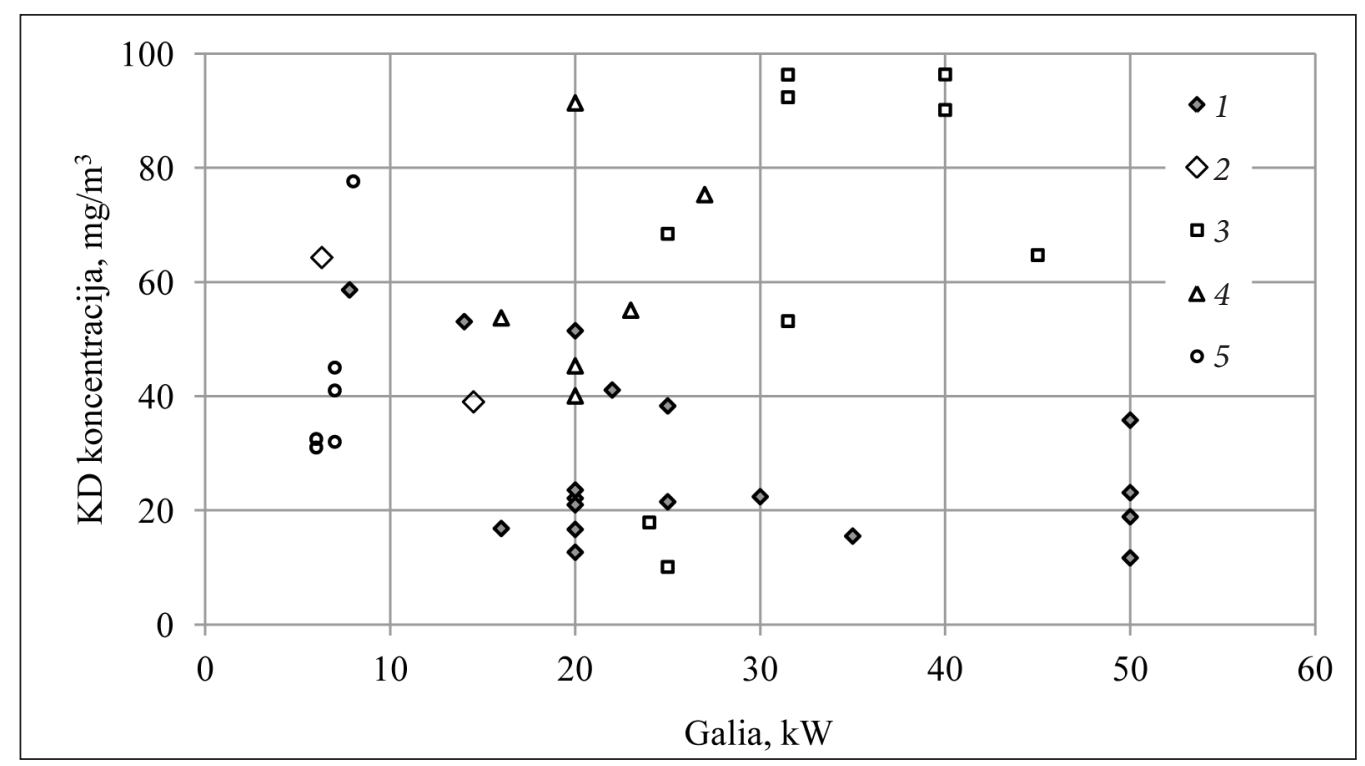

5 pav. Lietuvoje gaminamų mažos galios biokuru kūrenamų šildymo įrenginių vidutinès KD emisijų masès koncentracijos: 1 - medienos granulèmis kūrenami katilai; 2 - kaip ir (1), tik sumažinus katilų apkrovas; 3 - malkomis kūrenami (dujų generaciniai) katilai; 4 - malkomis kūrenami katilai; 5 - malkomis kūrenamos krosnelès 
Šie duomenys rodo, kad mažiausias KD emisijas išskiria šildymo įrenginiai, naudojantys specialiai paruoštą granuliuotą kurą bei turintys valdiklius, gebančius lanksčiai valdyti kuro ir oro tiekimą (5 pav., 1 taškas). Iš devyniolikos tirtų tokių katilų, esant vardinei galiai tik vieno jų, KD emisijos sieké $175 \mathrm{mg} / \mathrm{m}^{3}$, keturiolikos jų ( 74 \%) KD emisijos buvo $<40 \mathrm{mg} / \mathrm{m}^{3}$ ir atitiko reikalavimus, keliamus 5 klasės katilams [17]; keturių jų ( 21\%) emisijos buvo $<60 \mathrm{mg} / \mathrm{m}^{3}$ ir tenkino 4 klasès reikalavimus. Tačiau nustatytas KD emisijų didejjimas mažèjant katilų apkrovoms. Taip iš 5 pav. (2 taškai) matyti, kad esant 30 ir $50 \mathrm{~kW}$ vardinei katilų galiai, emisijos atitinkamai nuo 22,4 ir $23,1 \mathrm{mg} / \mathrm{m}^{3}$ padidejo iki 64,3 ir $39,0 \mathrm{mg} / \mathrm{m}^{3}$, jų galią sumažinus iki 6,3 ir $14,5 \mathrm{~kW}$.

Malkomis kūrenamų vandens šildymo katilų, neatsižvelgiant $i$ jų tipą, KD emisijų masès koncentracijos kito nuo $20 \mathrm{iki} 90 \mathrm{mg} / \mathrm{m}^{3}$ ir dauguma jų tenkino 4-5 klasès reikalavimus. Malkomis kūrenamoms krosnelèms dèl mažiau intensyvaus degimo, tinkamai sureguliavus ịsidegimą ir pirminio bei antrinio oro degimui tiekimą, pasiekiamas KD emisijų lygis $30-45 \mathrm{mg} / \mathrm{m}^{3}$. Reikia atkreipti dèmesị i tai, kad vienos krosnelès ir po vieną malkomis ir granulèmis kūrenamų katilų KD emisijos siekè $140-175 \mathrm{mg} / \mathrm{m}^{3}$, ir šie rezultatai 5 pav. nepateikti.

Apibendrinus gautus tyrimo rezultatus galima teigti, kad daugumos gaminamų mažos galios šildymo įrenginių KD emisijų masès koncentracijos tenkina dabar galiojančias normas. Tačiau kūrenant malkomis stebima gerokai didesnè $\mathrm{KD}$ emisijų masès koncentracijų sklaida, nei kūrenant paruoštu granuliuotu kuru ir taikant automatinio valdymo priemones kurui ir orui į degimo kamerą tiekti. Kadangi reikalavimai aplinkos taršai mažinti nuolat griežtėja, nenutrūkstamas dèmesys turi būti toliau skiriamas šildymo įrenginių konstrukcijoms tobulinti ir kurui iš anksto tinkamai paruošti, siekiant kuo efektyviau sudeginti įrenginyje kurą ir sumažinti aplinką teršiančias emisijas. Jau dabar aiškejja, kad negalima išsiversti be priemonių dūmams valyti, skirtų mažos galios įrenginiams, kūrenamiems kietuoju kuru, o pastaruoju metu ypač intensyviai populiarèjančiu kietuoju biokuru.

Tai susiję ir su vidutinès galios vandens šildymo katilais, kuriuose iprastiniai ciklonai ar multiciklonai vis dažniau įrengiami kartu su elektrostatiniais $\mathrm{KD}$ nusodintuvais arba medžiaginiais filtrais. Platus KD dydžių spektras, apimantis mažesnių kaip 0,5-1,0 $\mu \mathrm{m}$ dalelių intervalą, verčia, kaip matyti iš tyrimų apžvalgos ir toliau pateikiamų vidutinès galios vandens šildymo katilo KD emisijų tyrimo rezultatų, plètoti ịvairių priemonių arba ju sandaros taikymą, atsižvelgus ị biokuro panaudojimo sąlygas ir KD emisijų ypatumus.

\section{Multiciklono efektyvumo tyrimas}

Plètojant mažos galios šiluminių įrenginių, kūrenamų biokuru, KD taršos mažinimo tyrimus, eksploatacijos sąlygomis buvo tirtas vidutinès $(500 \mathrm{~kW})$ galios vandens šildymo katilo KD emisijų spektras ir ịvertintas 6 elementų multiciklono, skirto KD emisijoms mažinti, efektyvumas. Tokia priemonè dūmų dujoms valyti taikoma labai dažnai dèl jos paprastumo, turimos praktinès patirties, žinių apie jos efektyvumą didelès ir vidutinès galios įrenginiuose, pritaikytuose iškastiniam kurui. İrenginiams, kūrenamiems biokuru, iškyla išsamesnių tyrimų poreikis, atsižvelgus ị esminius KD emisijų spektrinès sudèties pokyčius ir jų didesnị jautrị ịrenginių tipui, galiai, veikimo režimams ir kuro sudeties nepastovumui.

Tyrimai atlikti katilui veikiant vardine galia ir deginant medžio skiedras ant ardyno. KD masès koncentracijos matuotos dūmtakio tiesiuose ruožuose $\sim 2 \mathrm{~m}$ atstumu prieš multicikloną ir po jo. $\mathrm{KD}$ masès koncentracijos matuotos automatiniu izokinetiniu KD rinktuvu Isostac Basic HV, kaip ir tiriant mažos galios įrenginių $\mathrm{KD}$ emisijas, vadovautasi reikalavimais, pateiktais [15] (žr. skyrių Lietuvoje gaminamu mažos galios įrenginiu KD emisijos). KD pasiskirstymas pagal dydi buvo matuojamas KD spektrometru Promo $3000 \mathrm{H}$ su dalelių jutikliais Welas 2100 ir $2500 \mathrm{HP}$, kurių matavimo ribos $0,2-40$ ir $0,7-105 \mu \mathrm{m}$ bei didžiausia daleliu koncentracija atitinkamai $5 \cdot 10^{5} \mathrm{ir} 4 \cdot 10^{3} \mathrm{~N} / \mathrm{cm}^{3}$ (čia $\mathrm{N}-$ dalelių kiekis vnt.). Spektrometro veikimo principas pagristas dalelès, judančios optiškai apibrežtame ir apšviestame baltąja šviesa matavimo tūryje, išbarstytos šviesos analize. Dalelių kiekis nustatomas pagal išbarstytos šviesos impulsų dažní, dalelių dydis - pagal impulsų amplitudę. Mèginiai buvo paimami KD rinktuvu iš dūmtakio prieš multicikloną ir po jo tuose pat taškuose, kuriuose buvo matuojama dalelių masès koncentracija. Multiciklone sulaikytų dalelių mėginiai buvo imami tiesiogiai iš multiciklono kameros. Laboratorijoje mèginiai patalpinti ị specialų indą, kurị kratant arba filtrą su 
dalelemis apipučiant oro srove buvo sudaromas dalelių rūkas, kuris siurbiamas nustatytu debitu per jutiklio kamerą.

Multiciklono efektyvumas įvertinamas pagal KD rinktuvu surinktų dalelių prieš multicikloną ir po jo svorių skirtumą. Matavimo ir skaičiavimo rezultatai pateikti 5 lentelèje. Apskaičiuojant KD masès koncentracijas buvo įvertinti dūmų temperatūros ir slègio skirtumai prieš multicikloną ir po jo.

Kaip matyti iš šios lentelès, multiciklono efektyvumo rezultatų vidurkis sudare $38,2 \%$. Palyginus su duomenimis, pateiktais 3 pav., ši efektyvumo reikšmė neblogai koreliuoja su ciklonų efektyvumu, atsižvelgus it dūmuose esančių ir multiciklone sulaikytų KD spektrus. 6 pav. pateikti rezultatai rodo, kad multiciklone sulaikytu dalelių dydis kinta nuo 1 iki $10 \mu \mathrm{m}$, bet daugiausia sulaikyta dalelių, kurių dydis nuo 2 iki $5 \mu \mathrm{m}$.

Šis rezultatas gerai koreliuoja su mèginių, paimtų prieš multicikloną ir po jo, analizès rezultatais, pateiktais 7 pav. Matyti, kad katilo, kūrenamo me- dienos skiedromis, dūmuose didžiausias $\mathrm{KD}$ tankis pagal dalelių dydi yra intervalo $0,2-0,5 \mu \mathrm{m}$ viduryje. Taip pat aiškiai matoma, kad dūmuose yra $\mathrm{KD}$, kurių dydis didesnis nei $1 \mu \mathrm{m}$, ir intervale nuo 2 iki $6 \mu \mathrm{m}$ yra antras lèkštas pikas, bet gerokai mažesnis nei 0,2-0,5 $\mu \mathrm{m}$ intervale. Toliau didejjant $\mathrm{KD}$ dydžiui, jų tankis smarkiai mažèja. Po multiciklono $\mathrm{KD}$ didžiausias tankis stebimas tame pačiame intervale kaip prieš multicikloną, bet jo pikas yra sumažèjęs ir nebèra antrojo aiškaus piko spektre, kai dalelių dydis didesnis nei $1 \mu \mathrm{m}$.

Iš šių rezultatų darytina išvada, kad katilo, kūrenamo medienos skiedromis, KD emisijose daugiausia yra smulkiųjų $0,2-0,5 \mu \mathrm{m}$ dydžio dalelių. Multiciklone sulaikoma daugiausia dalelių, kurių dydis yra 1-10 $\mu \mathrm{m}$ intervale. Kartu su stambiosiomis dalelèmis sulaikoma nedidelè dalis smulkiujų dalelių (7 pav.). Toks KD spektras leidžia daryti prielaidą, kad smulkiosios dalelès turi didelę ịtaką masès koncentracijos reikšmėms, pagal kurias nustatomas multiciklono efektyvumas.

5 lentelè. Multiciklono efektyvumo tyrimo rezultatai

\begin{tabular}{|c|c|c|c|c|c|c|c|}
\hline \multirow{2}{*}{ Matavimo vieta } & \multicolumn{2}{|c|}{ Bandinių svoriai bruto, $\mathbf{g}$} & \multirow{2}{*}{$\begin{array}{c}\text { Svorių } \\
\text { skirtumas, } \\
\text { g }\end{array}$} & \multirow{2}{*}{$\begin{array}{c}\text { Dujų } \\
\text { méginio } \\
\text { tūris, } \text { m }^{3}\end{array}$} & \multirow{2}{*}{$\begin{array}{c}\text { Duju } \\
\text { debitas, } \\
\mathbf{m}^{3} / \mathbf{h}\end{array}$} & \multirow{2}{*}{$\begin{array}{c}\text { KD masès } \\
\text { koncentracija, } \\
\mathrm{mg} / \mathrm{Nm}^{3}\end{array}$} & \multirow{2}{*}{$\begin{array}{c}\text { Ciklono } \\
\text { efektyvumas, } \\
\%\end{array}$} \\
\hline & Prieš bandymą & Po bandymo & & & & & \\
\hline \multirow{3}{*}{$\begin{array}{c}\text { Prieš } \\
\text { multicikloną }\end{array}$} & 16,39669 & 16,45614 & 0,05945 & 0,3148 & 1608 & 158,78 & \multirow{6}{*}{38,2} \\
\hline & 15,55603 & 15,61274 & 0,05671 & 0,2865 & 1451 & 166,43 & \\
\hline & 14,71991 & 14,76703 & 0,04712 & 0,2852 & 1467 & 138,91 & \\
\hline \multirow{3}{*}{$\begin{array}{c}\text { Po } \\
\text { multiciklono }\end{array}$} & 16,12115 & 16,15699 & 0,03584 & 0,2858 & 1502 & 105,44 & \\
\hline & 14,67184 & 14,70461 & 0,03277 & 0,2990 & 1534 & 92,15 & \\
\hline & 14,77444 & 14,80545 & 0,03101 & 0,2927 & 1512 & 89,08 & \\
\hline
\end{tabular}

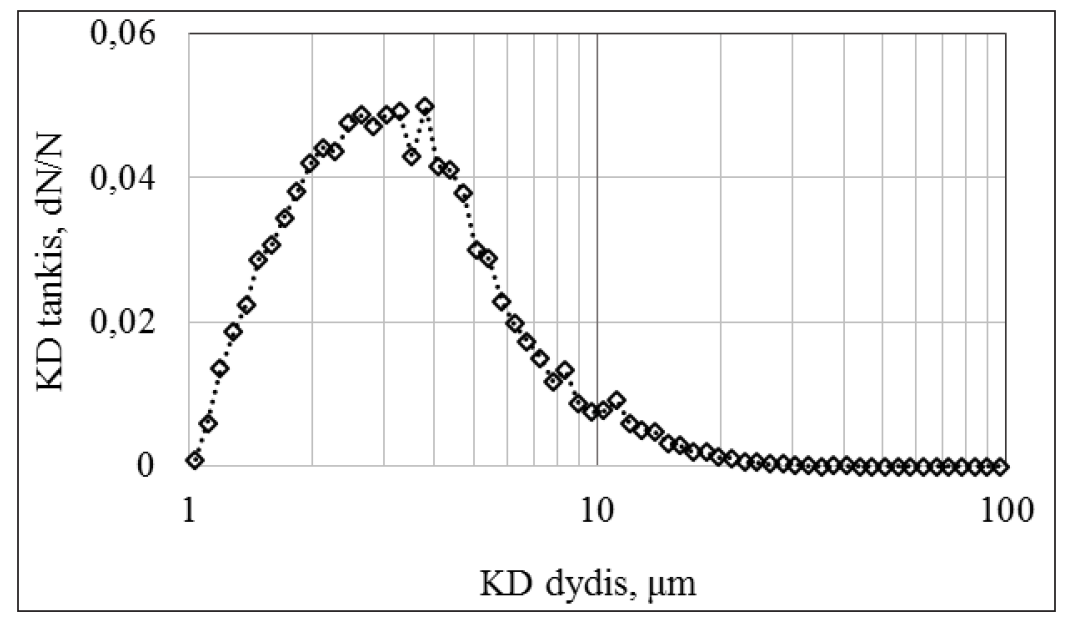

6 pav. Multiciklone sulaikytų KD kiekio (tankio) pasiskirstymas pagal dalelių dydi 


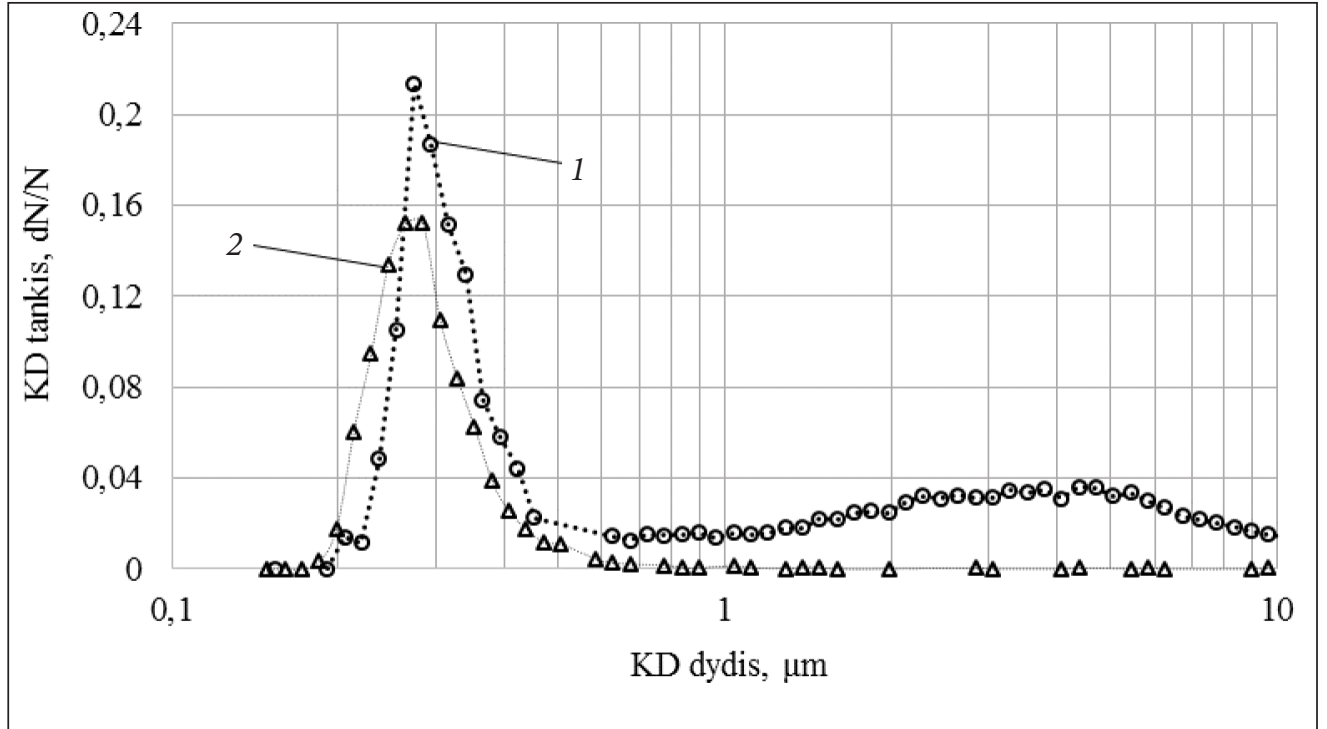

7 pav. KD kiekio (tankio) pasiskirstymas pagal jų dydi: 1 - prieš multicikloną; 2 - po multiciklono

Jei multiciklonas nesulaiko smulkiujų dalelių, jo efektyvumas negali būti labai aukštas.

Palyginus su apžvalgoje pateiktais darbų [1013] rezultatais ir 3, 4 pav. duomenimis, nustatytas multiciklono efektyvumas patenkinamai koreliuoja su ciklonams ir multiciklonams būdingomis efektyvumo reikšmèmis. Galima netgi iž̌velgti multiciklono gebėjimą efektyviau nei ciklonas sulaikyti smulkesnes daleles, bet tam patvirtinti reikia išsamesnių tyrimų. Vis dèlto yra pakankamai duomenų, leidžiančių tvirtinti, kad praktinès ciklono ir multiciklono taikymo galimybès KD emisijoms mažinti iš ịrenginių, kūrenamų biokuru, yra ribotos dèl labai didelio kiekio smulkiuju dalelių, ir negalima apsieiti be papildomų ar kito tipo priemonių, kurios gebètų dūmus nuo šių dalelių valyti. Būtent todèl didesnès galios įrenginiams taikomas dviejų pakopų valymas, kai antroje pakopoje ìrengiami elektrostatiniai KD nusodintuvai arba ìvairios rūšies filtrai. Kadangi biokuro naudojimas mažos galios buitiniuose įrenginiuose plečiasi, analogiškus uždavinius būtina spręsti ir šioje srityje, įvertinus visus jos savitumus.

\section{IŠVADOS}

1. Eksperimentiškai ištyrus Lietuvoje gaminamų mažos nuo 6 iki $50 \mathrm{~kW}$ galios biokuru kūrenamų šildymo įrenginių, neturinčių dūmų valymo ịrangos, KD emisijų masès koncentracijas, nustatyta, kad granuliuotu kuru kūrenamų vandens šildymo katilu KD emisijos yra mažiausios. Iš devyniolikos tirtų tokių katilų, esant vardinei galiai, $74 \%$ jų $\mathrm{KD}$ emisijos buvo $<40 \mathrm{mg} / \mathrm{m}^{3}$ ir atitiko reikalavimus, keliamus 5 klasės katilams; $21 \%$ jų KD emisijos buvo $<60 \mathrm{mg} / \mathrm{m}^{3}$ ir tenkino 4 klasès reikalavimus. Mažinant katilų apkrovas, KD emisijos gerokai didejja.

Malkomis kūrenamų katilų, neatsižvelgiant ị jụ tipą, KD emisijų masès koncentracijos kito nuo 20 iki $90 \mathrm{mg} / \mathrm{m}^{3}$ ir dauguma jų tenkino $4-5$ klasès reikalavimus. Malkomis kūrenamoms krosnelèms dèl mažiau intensyvaus degimo, tinkamai sureguliavus ìsidegimą ir pirminio bei antrinio oro degimui tiekimą, pasiekiamas KD emisijų lygis $30-45 \mathrm{mg} / \mathrm{m}^{3}$.

2. Medienos skiedromis kūrenamo vidutinès $(500 \mathrm{~kW})$ galios vandens šildymo katilo dūmuose esančių KD dydžio ir tankio bei už katilo įrengto 6 elementų multiciklono veikimo efektyvumo tyrimais nustatyta, kad KD emisijose yra daugiausia $0,2-0,3 \mu \mathrm{m}$ dydžio dalelių, kurios lemia ir KD masès koncentracijos reikšmes. Multiciklone sulaikomos dalelių kiekis didžiausias 2-5 $\mu \mathrm{m}$ intervale. Nors multiciklone iš dalies taip pat sulaikomos smulkiosios dalelès, bet siekiant užtikrinti mažas KD emisijas iš įrenginių, kūrenamų biokuru, svarbu naudoti papildomą îrangą, kuri leidžia sumažinti smulkiųjų KD kiekį.

3. Eksperimentiniai rezultatai gerai koreliuoja su atliktos trumpos, kietuoju biokuru kūrenamų irenginių KD emisijų charakteristikų ir jų mažinimo metodų, apžvalgos rezultatais. Patvirtinamas 
būtinumas naudojant tokị kurą taikyti metodus ir įrangą, užtikrinančius KD smulkesnių nei $1 \mu \mathrm{m}$ sulaikymą. Elektrostatiniai $\mathrm{KD}$ nusodintuvai ir medžiaginiai arba keraminiai filtrai leidžia pasiekti geriausių rezultatų ir jų taikymo tyrimai sparčiai plètojami.

Gauta 20151001

Priimta 20151125

\section{Literatūra}

1. Kuro ir energijos balansas 2014. Lietuvos statistikos departamentas, 2015. P. 1-54.

2. Lillieblad L., Strand M., Porle K. Conditions for electrostatic precipitators after biomass fired boilers. Papers of IX International Conference on Electrostatic Precipitation (ICESP IX), May 17-21, 2004, Mpumalanga, South Africa.

3. Johansson L. Characterisation of Particle Emissions from Small-scale Biomass Combustion. Thesis for the Degree of Licentiate of Engineering. Chalmers University of Technology, Goteborg Sweden, 2002.

4. Jenkins B. M., Baxter L. L., Miles Jr. T. R., Miles T. R. Combustion properties of biomass. Fuel Processing Technology. 1998. Vol. 54. P. 17-46.

5. Szpila A., Pagels J., Strand M., Lillieblad L., Gudmundsson A., Risler J., Swietlicki E., Bohgard M., Sanati M. Experimental studies on particle emissions from grate fired biomass combustion Boilers. Proceedings from the 12th European Conference and Technology Exhibition on Biomass for Energy Industry and Climate Protection, June 17-21, 2002, Amsterdam, the Netherlands.

6. Lind T. Ash Formation in Circulating Fluidised Bed Combustion of Coal and Solid Biomass. PhD Thesis, Espoo, Finland, VTT Publication No. 378. 1999.

7. Bauchemin P. A., Tampier M. Emissions from Wood-Fired Combustion Equipment. Report for British Columbia Ministry of Environment. Envirochem Services Inc., North Vancouver B. C., June 30, 2008.

8. Nussbaumer T., Klippel N., Johansson L. Survey on measurements and emission factors on particulate matter from biomass combustion in IEA countries. 16th European Biomass Confer- ence and Exhibition, 2-6 June 2008, Valencia, Spain - Oral Presentation OA 9.2.

9. Obernberger I., Mandl C. Survey on the Present State of Particle Precipitation Devices for Residential Biomass Combustion with a Nominal Capacity up to $50 \mathrm{~kW}$ in IEA Bioenergy Task 32 Member Countries. IEA Bioenergy TASK32 report, Final version. Institute for Process and Particle Engineering, Graz University of Technology, Austria 2011.

10. Hinckley J., Doshi K. Emission Controls for Small Wood Fired Boilers. Report for United States Forest Service, Western Forestry Leadership Coalition. Resource Systems Group, Inc. 55 Railroad Row, White River Junction; Biomass Energy Resource Center, 43 State Street, Montpelier, USA, May 2010.

11. Hamilton S., Fleming S., Stewart R. The Assessment of Flue Gas Particulate Abatement in Wood Burning Boilers. Report for Forestry Commission Scotland Restricted Commercial ED56285 Issue Number 3. December 2010.

12. Zhao Bing-Tao. Effects of flow parameters and inlet geometry on cyclone efficiency. The Chinese Journal of Process Engineering. 2006. Vol. 6. No. 2. P. $178-180$.

13. Peng W., Alex C. Hoffmann, Dries H. Separation characteristics of swirl-tube dust separators AIChE Journal. 2004. Vol. 50. No. 1. P. 87-96.

14 Faulkner W. B., Buser M. D., Whitelock D. P., Shaw B. W. Effects of cyclone diameter on performance of 1D3D cyclones: collection efficiency. Journal of American Society of Agricultural and Biological Engineers (ASABE). 2007. Vol. 50. No. 3. P. 1053-1059.

14. Stacionariųjų šaltinių išmetamieji teršalai. Mažos masès dulkių koncentracijos nustatymas. 1 dalis. Rankinis gravimetrinis metodas. Standartas LST EN 13284-1:2006.

15. Vonžodas T., Pedišius N., Valantinavičius M. Mažos galios biokuru kūrenamų vandens šildymo katilų veikimo parametrų tyrimas. Energetika. 2013. T. 59. Nr. 2. P. 93-103.

16. Šildymo katilai. 5 dalis. Rankomis ir automatiškai pakraunami kietojo kuro šildymo katilai, kurių šiluminé galia iki $500 \mathrm{~kW}$. Terminija, reikalavimai, bandymai ir ženklinimas. Standartas LST EN 303-5:2012. 
Jurij Tonkonogij, Nerijus Pedišius,

Arūnas Stankevičius, Andrius Tonkonogovas

INVESTIGATION OF PARTICULATE

MATTER EMISSION FROM LOW- AND MIDDLE-CAPACITY BOILERS FIRED WITH SOLID BIOFUEL

\section{Summary}

Mass concentration of particulate matter (PM) emission from heating appliances of low capacity from 6 to $50 \mathrm{~kW}$ fired by solid biofuel that are manufactured in Lithuania and do not have fume gas cleaning systems was experimentally investigated. It was assessed that PM emissions of hot water boilers fired with pelletized fuel were the lowest. PM emissions from $74 \%$ of nineteen investigated boilers at rated output were $<40 \mathrm{mg} / \mathrm{m}^{3}$ and met the requirements for Class 5 boilers; PM emissions from 21\% of them were $<60 \mathrm{mg} / \mathrm{m}^{3}$ and satisfied the requirements of Class 4. Mass concentrations of PM emissions from boilers fired with logs, regardless of their type, ranged from 20 to $90 \mathrm{mg} / \mathrm{m}^{3}$ and most satisfied Class (4-5). PM emissions level from logs-fired ovens due to less intensive combustion and at the proper adjustments of ignition phase and the primary and secondary combustion air supply ranged within (30-45) $\mathrm{mg} / \mathrm{m}^{3}$.
Investigation of PM size and density in flue gases of $500 \mathrm{~kW}$ water heating boiler fired with wood chips was carried out. Operation efficiency of a 6-battery multicyclone mounted downstream boiler and density distribution of PM up to the multicyclone and down it by size were investigated. It was found that the particle emissions were mainly (from 0.2 to 0.3 ) $\mu \mathrm{m}$. The largest quantity of particles seized in the multicyclone was in (2-5) $\mu \mathrm{m}$ range. Although the multicyclone also partly seized small particles, but in order to ensure low PM emissions from installations fired with biofuels, it is important to use additional measures that allow reducing the amount of fine PM. Experimental results correlate well with results of a brief survey of PM emission characteristics and their cleaning methods from installations fired with solid biofuel. Using such fuel, the necessity is confirmed to apply such methods, installations that ensure detention of PM smaller than $1 \mu \mathrm{m}$. Electrostatic precipitators and fabric or ceramic filters provide the best results, and investigations of their application in practice are fast-developing.

Key words: particulate matter emission, biomass, boiler, cyclone efficiency 